\title{
KAJIAN BAHASA RUPA KARTUN KOMIK BENNY RACHMADI DALAM BUKU PR BUAT PRESIDEN
}

\author{
Humrotin \\ Desain Komunikasi Visual \\ Fakultas Seni Rupa ISI Yogyakarta
}

\begin{abstract}
Giving out facts or speaking through cartoon comics is one of then many from of social interaction. By using this method one needs to understand the language visual grammar so people will understand. Benny Rachmadi is one of the successful cartoonist which have grasps the understanding of using cartoon comics to talk to the public. During the presidential election on July 2014, Benny republish his selected work in a book called "Homework for the President".

To understand the style and form of communication in Benny Rachmasdi's comic, this research uses qualitative method using the theory of visual language. The theory of visual language is divided to three steps, wimba content, wimba process, inner and outer expression. The sample are chosen to represent cartoon comic in non-monologue and non dialogue and also in monologue and dialogue.

This research shows that wimba content of Rachmadi's comic uses representations of the actual figure involved with the topic. Wimba process are taken from the most dominant feature, using thick and thin lines, compact composition and balance layout both visually and verbally. Inner expressions use dramatic and hyperbolic expression. The metaphoric concept is obtained through combing the main thought with other relevant reference. The outer expression is close to the visual language of east.
\end{abstract}

Keywords: Cartoon, Comic, Visual language, Benny Rachmadi, Style and Form.

Relevance to Visual Communication Design Practice: This research can be used as visual language concept paradigm to create cartoon comic.

\section{A. LATAR BELAKANG MASALAH}

Tahun 2014 kemarin, tepatnya pada tanggal 9 Juli, negara Indonesia melaksanakan pemilihan umum presiden dan wakil presiden ke 16. Sejumlah apresiasi publik tampil dalam berbagai macam bentuk, memuat kritik, saran, harapan, dukungan, maupun penolakan. Setiap warga negara Indonesia dari berbagai macam latar belakang memiliki cara masing-masing dalam mengekspresikan emosinya sebagai wujud reaksi atas momen tersebut. Para pekerja seni, khususnya desainer komunikasi visual cenderung memilih jalan berkarya untuk melayangkan kritik kepada pemerintah.
Bukan perkara mudah ketika bicara komunikasi desain, ada banyak sisi yang menjadi bahan pertimbangan dalam mencipta karya, apalagi dalam bentuk kartun komik yang memuat isu-isu sosial politik. Sesuatu yang sifatnya serius dan rumit harus dikemas menjadi lebih sederhana, padat dan jelas. Pesan maupun kritik harus terasa lebih asyik, menarik dan menggelitik, terpenting dari unsur-unsur tersebut adalah bagaimana cara menjadikan karya agar terasa lebih hidup serta tidak menimbulkan salah tafsir.

Meskipun zaman sekarang sudah berbeda dengan zaman dulu, dimana kebebasan pers dibatasi, bukan berarti kartunis bisa berekspresi menuruti kehendak 
hati. Sudah bukan rahasia lagi bahwasannya profesi sebagai seorang kartunis yang karyanya memuat respon terhadap tingkah pola elit politik yang tidak sedap dipandang mata memiliki konsekuensi tersendiri. Kritik yang tajam dan menghujam masih berpeluang mengundang ancaman bahkan mengantarkan kartunis pada urusan pidana. Sedangkan kritik yang tampil lembek cenderung sulit dicerna dan cepat dilupakan begitu saja.

Salah satu kartunis terkenal yang sebelumnya telah sukses melayangkan kritik adalah Benny Rachmadi. Menyambut pemilu presiden dan wakil presiden, Benny Rachmadi kembali hadir dengan sejumlah pekerjaan rumah yang disodorkan pada presiden terpilih dalam bentuk kartun komik. Benny merangkum karya kartun opininya dalam satu buku yang diberi judul "PR buat Presiden”. Dalam buku tersebut berbagai permasalahan korupsi, politik, ekonomi, bencana alam, premanisme, hukum, dan kriminal disajikan dengan gaya khas Benny. Gaya Benny "berbicara" adalah resep yang bisa menjadi bahan pelajaran bagi para desainer komunikasi visual dalam menyampaikan pesan terutama pesan berbau kritik sosial politik. Oleh sebab itu perlu adanya pemahaman lebih jauh mengenai cara bertutur seorang Benny Rachmadi dilihat dari kacamata bahasa rupa. Terutama gaya Benny yang sekarang, saat peralihan kekuasaan, saat dimana harapan muncul ke permukaan dan permasalahan meminta uluran tangan.

\section{B. Rumusan Masalah}

Bagaimana bahasa rupa kartun komik Benny Rachmadi dalam buku PR buat Presiden?

\section{Teori dan Metode Penelitian}

Analisis menggunakan metode deskriptif kualitatif, yakni menuliskan hasil penelitian secara naratif seperti orang sedang bercerita dari pembahasan umum kemudian ke khusus (indukif) untuk mendapat kesimpulan. Penelitian ini akan dibedah menggunakan teori bahasa rupa. Teori ini merupakan hasil dari penelitian yang dilakukan oleh Primadi Tabrani dalam studi komparasi antara bahasa rupa Barat dengan bahasa rupa Timur dalam konteks bercerita. Objek kajian menggunakan gambar kasatmata dwimatra. Dalam bukunya, Primadi menyebut tata bahasa rupa orang Barat menggunakan sistem Naturalis Perspektif Moment Opname (NPM), maksudnya adalah menyajikan gambar dalam satu arah, satu tempat dan satu waktu. Sedangkan tata bahasa rupa Timur menggunakan sistem Ruang Waktu Datar (RWD), dimana gambar dalam satu frame menampilkan aneka jarak, aneka ruang, dan aneka waktu, artinya gambar tersebut dapat bercerita.

Cara analisis bahasa rupa terbagi atas isi wimba, cara wimba, tata ungkapan dalam, dan tata ungkapan luar. Yang dimaksud dengan isi wimba adalah objek yang digambar, cara wimba adalah bagaimana objek tersebut digambarkan (tampak samping atau tampak depan, besar atau kecil dan sebagainya), tata ungkapan dalam adalah cara menyusun wimba dan cara wimbanya, tetapi penataan tersebut memiliki tujuan untuk mengungkap makna yang terkandung dalam satu bingkai gambar. Dan bagian terakhir adalah Tata ungkapan luar yang merupakan cara memahami dan merangkai peralihan antar tata ungkapan dalam yang satu dengan tata ungkapan dalam yang lainnya sehingga 
terbentuk cerita yang utuh. Teori bahasa rupa akan dihubungan dengan pemapamaran Scott McCloud dalam buku Understanding Comics. Hal ini dilakukan mengingat objek kajian berupa kartun komik.

\section{Pembahasan}

\section{Kartun Non-Monolog Non-Dialog}

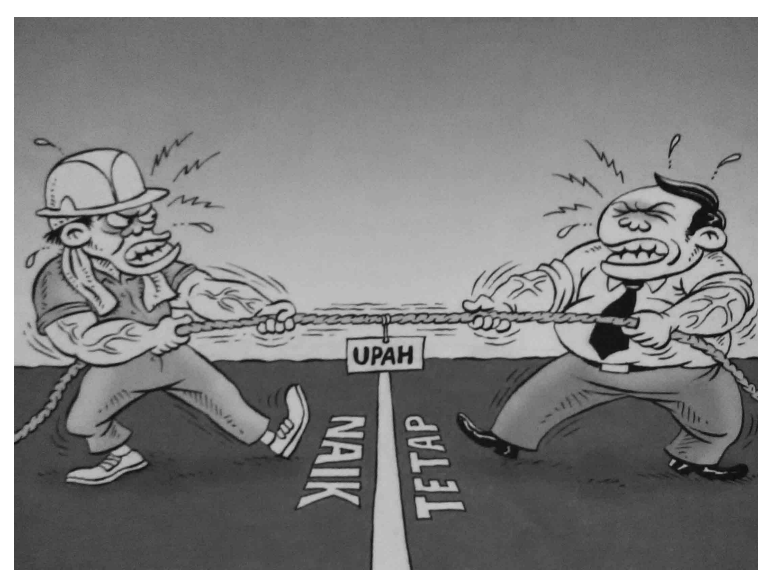

Gambar 1 Kartun Komik "Adu Otot Kenaikan UMP 2014"

(Sumber: Benny Rachmadi, 2014)

\section{a. Isi Wimba}

Kartun komik memperlihatkan dua orang pria sedang tarik-menarik tali tambang. Pria di sebelah kiri berbadan atletis, tangannya berotot, rambutnya pendek warna hitam, memakai baju model terusan, kedua lengan bajunya dilipat sampai di atas siku, memakai helm, mengantungkan handuk di leher, memakai sepatu tali warna putih, dan wajahnya tampak geram. Pria di sebelah kanan berbadan gemuk, wajah bulat, perut buncit, tangan berotot, rambut pendek warna hitam, memakai kemeja berkerah, kedua lengan baju dilipat sampai siku, celana panjang, sepatu, dasi, dan ikat pinggang. Di tengah-tengah tali diantara dua pria tersebut tergantung benda persegi panjang bertuliskan
"UPAH". Tepat di bawah tulisan "UPAH", pada lantai pijakan terdapat garis panjang yang di samping kiri garis tertera tulisan "NAIK" dan di samping kanan tertera tulisan “TETAP”.

\section{b. Cara Wimba}

Konsep gambar bercerita mengenai tarik menarik tali tambang antara buruh bangunan dan pengusahan, keduanya digambar dari sudut paling karakteristik, yakni tiga perempat tampak depan kecuali sepatu, digambar tampak samping. Dua pemain tarik tambang terhubung sebuah tali dimana di tengah-tengahnya tergantung sign bertuliskan "UPAH”, berfungsi sebagai penanda seberapa jauh pemain dapat menarik lawan. Tepat di bawah sign, yakni pada lantai terdapat garis panjang, berfungsi sebagai pembatas wilayah antar pemain sekaligus identifikasi pihak “juara” dan pihak yang "kalah". Kemudian di samping kiri garis tertera teks "NAIK" dan di samping kanan tertera teks "TETAP", ditulis manual menggunakan huruf sans serif. Garis dan dua kata tersebut berwarna putih, disusun secara vertikal dan digambar perspektif satu titik hilang. Lantai berwarna hitam sedangkan background bergradasi dari atas berwarna gelap semakin ke bawah semakin terang.

Kartun digambar menggunakan eye level, long shot, permainan value hitam putih dan teknik arsir untuk memberikan kesan trimatra dan efek kontras. Semua garis menggunakan garis tebal tipis yang menjadikan adanya kesan kesatuan yang harmonis dan seirama. Cara penataannya membentuk keseimbangan simetris dan memberikan focal point (sign). Cara baca dapat dimulai dari berbagai sisi, karena tidak 
terdapat unsur yang menerangkan kejadian awal maupun akhir.

\section{c. Tata Ungkapan Dalam}

Kartun komik ini merupakan kartun komik editorial, fungsinya merekam kejadian teraktual pada masa tertentu. Berdasarkan penulusuran pada situs resmi majalah Kontan, kartun komik ini berjudul "Adu Otot Kenaikan UMP 2014”, diposting hari Rabu 23 Oktober 2013. Konflik yang terjadi pada bulan tersebut adalah tarik-menarik antara buruh dan pengusaha terkait penetapan upah minimum provinsi (UMP). Menurut berita dari liputan6.com, para buruh di seluruh Indonesia mengajukan lima tuntutan dan berencana mogok kerja nasional pada tanggal 31 Oktober 2013 dan 1 November 2013.

Konflik tersebut divisualkan dalam wujud permainan tarik tambang. Konsep tarik tambang dianggap mempunyai kesesuaian dengan konflik buruh dan pengusaha, keduanya sama-sama harus dilakukan oleh dua pihak dan menuntut para pemain saling beradu untuk menjatuhkan lawan. Kedunya terhubung satu kata kunci, yakni "tarik menarik".

Menggunakan tokoh yang terlibat langsung dengan konflik, yakni buruh dan pengusaha. Berbagai profesi buruh diwakilkan oleh buruh bangunan, karena buruh bangunan adalah buruh yang paling kuat sehingga mampu merepresentasikan kondisi buruh pada saat konflik sedang berlangsung. Penempatannya (di sebelah kiri) menjelaskan buruh merupakan pihak yang memulai jalannya konflik. Kemudian di sebelah kanan ditempati oleh wimba pengusaha.
Lima tuntutan diwakilkan oleh kata "UPAH". Menurut kamus besar bahasa Indonesia, upah adalah uang dan sebagainya yang dibayarkan sebagai pembayar jasa atau tenaga yang sudah dikeluarkan untuk suatu pekerjaan. Hal ini bisa jadi merupakan alasan Benny tidak membubuhkan simbol uang seperti \$ atau "Rp" (rupiah) dalam sign.

Gambar membentuk keseimbangan simetris, memberikan pemaknaan bahwa wacana mengenai kenaikan upah UMP belum mencapai final, kedua belah pihak masih dalam posisi sejajar. Tetapi disini Benny sudah mulai menerka-nerka akhir dari konflik tersebut akan dimenangkan oleh pihak buruh. Tebakan tersebut ditunjukkan melalui garis gerak pada siku kiri pengusaha yang dibuat meliuk-liuk (tanda gemetar) dan garis gesture buruh bangunan dibuat lebih miring ke belakang daripada gesture pengusaha, menandakan porsi kekuatan buruh bangunan lebih besar.

\section{Kartun Dialog}

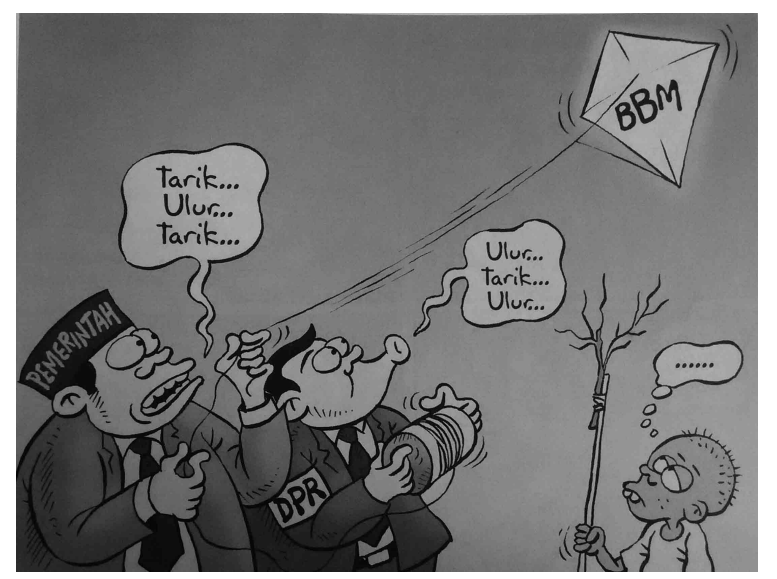

Gambar 2 Kartun Komik “Tarik Ulur Harga BBM"

(Sumber: Benny Rachmadi, 2014) 


\section{a. Isi Wimba}

Gambar dalam kartun komik di atas terdiri dari dua pria dewasa sedang menerbangkan layang-layang dan seorang rakyat jelata sedang melihat layang-layang. Layang-layang tersebut berada di pojok kanan atas bertuliskan "BBM" dan tubuhnya terhubung langsung dengan pria di pojok kiri bawah melalui benang. Pria pertama berada di posisi paling kiri, digambar setengah badan dalam tampilan formal, berbadan gemuk, wajah bulat, kulit putih, rambut hitam, mata melihat ke layang-layang, memakai kemeja, jas kantor, dasi dan penutup kepala bertuliskan "PEMERINTAH". Di atasnya terdapat balon ucapan berisi tulisan “Tarik...Ulur...Tarik...”. Pria kedua berada di sebelah kanan pria pertama, penampilannya tidak jauh berbeda dengan pria pertama. Bedanya pada lengan kanan pria kedua ini terdapat belt putih bertuliskan "DPR" dan tidak memakai penutup kepala. Di atasnya terdapat tulisan "Ulur...Tarik...Ulur..."

Di bagian kanan bawah ditempati rakyat jelata yang sedang melihat layanglayang, digambar setengah badan, tampak dekil, dua gigi maju ke depan, rambut tumbuh dalam jarak yang berjauhan, memakai kaos putih, tangan kanannya ditekuk ke atas sambil memegang tongkat kayu yang bagian atasnya disambung dengan ranting pohon. Tepat di atas kepalanya terdapat balon pikiran berisi tanda titik berulang sebanyak enam kali.

\section{b. Cara Wimba}

Berdasarkan gambar, kartun komik bercerita mengenai pemerintah dan DPR yang sedang menerbangkan layang-layang di depan rakyat jelata. Bentuk dasar layang-layang yang dimainkan menyerupai bidang segi empat bertuliskan "BBM". Bentuk layang-layang tersebut merupakan bentuk yang paling umum dan mudah dijumpai di berbagai tempat.

Wimba rakyat jelata, pemerintah dan DPR digambar dari sudut tiga perempat tampak depan di atas background bergradasi dari gelap ke terang dalam ukuran mid shot. Posisi pemerintah dan DPR dibuat menumpuk, membentuk ruang di dalam bidang dwimatra. Tata letak wimba membentuk keseimbangan asimetris, dimana muatan di sisi kanan dan di sisi kiri sama besar tetapi berbeda wujud. Unsur visual dan verbal kartun komik saling melengkapi kekosongan informasi satu sama lain (interdependent).

Semua garis visual maupun verbal menggunakan jenis garis tebal tipis sehingga terlihat adanya kesan kesatuan. Semua teks menggunakan huruf cursive, huruf yang didesain berdasar pada tulisan tangan. Teks dialog menujukkan adanya durasi waktu, oleh sebab itu kartun komik harus dibaca dari waktu yang lebih lampau. Menurut kebiasaan tata bahasa sehari-hari masyarakat Indonesia, kata "tarik" diucapkan lebih dulu baru kemudian dilanjutkan dengan kata "ulur". Jadi, membaca kartun komik ini dimulai dari kiri ke kanan.

c. Tata Ungkapan Dalam.

Kartun komik ini diunggah di situs resmi majalah Kontan pada Senin 19 Maret 2012 dengan judul "Tarik Ulur Harga BBM". Masalah yang sebenarnya terjadi sekitar maret 2012 adalah rencana pemerintah 
menaikkan harga BBM bersubsidi. Permasalahan tersebut dikemas kembali oleh Benny dalam kartun komik yang menggelitik. Para wakil rakyat yang seharusnya duduk manis di kursi pemerintahan digambarkan dengan pendekatan parodi, yakni menangani masalah harga BBM bersubsidi bagaikan bermain layang-layang yang dapat ditarik dan diulur sekehendak hati.

Benny membuat perumpamaan melalui pendekatan bahasa, mencari satu kata kunci yang mewakili masalah tersebut dan dicari padanannya dengan konteks lain. Kata kunci yang digunakan adalah tarik-ulur, kata tersebut kemudian disandingkan dengan permainan layang-layang. Pemilihan layanglayang dikarenakan permainan ini tidak hanya dekat dengan kata tarik dan ulur tetapi juga memperlihatkan kondisi naik dan turun seperti harga BBM.

Layang-layang dimainkan oleh dua orang, yakni pemerintah sebagai pemegang kendali layang-layang dan DPR membantu membawa kaleng tempat benang layanglayang dililitikan. Konsep bermain ganda biasanya dilakukan oleh pemain yang belum mahir memainkan layang-layang. Itu artinya pemerintah dan DPR diceritakan sebagai pihak yang tidak cukup ahli dalam mengatur strategi menghadapi dilematika penetapan harga BBM.

Pemerintah sebagai pemegang kendali layang-layang menujukkan bahwa pihaknya mempunyai kekuasaan tertinggi untuk menentukan harga BBM. Pemerintah dibantu oleh DPR dalam memainkan layang-layang. DPR bertugas membawa kaleng bekas tempat mengulur dan melingkarkan benang agar tidak kusut. Dalam bahasa Jawa, kaleng tempat benang disebut bendrong dan orang yang membawanya disebut mbendrong. Peran DPR sendiri di dunia nyata tidak jauh berbeda dengan perannya dalam gambar, yakni membantu kinerja Pemerintah mengelola kehidupan bernegara.

DPR dan pemerintah terlihat fokus pada layang-layang, mereka mengabaikan rakyat jelata yang berada dihadapannya. Rakyat jelata diwakilkan oleh anak kecil, karena kondisi anak kecil mirip dengan rakyat jelata yang sama-sama belum mandiri dan masih menggantungkan hidup kepada "atasannya" (anak kecil bergantung pada orang tua dan rakyat jelata bergantung pada kebijakan pemerintah). Tangan kanan rakyat jelata membawa tongkat panjang, menunjukkan kalau dia sedang menunggu layang-layang jatuh. Tepat di atas kepala rakyat jelata ini tergambar balon pikiran berbentuk meliuk berisi deretan enam titik, sebuah analogi dari kekosongan dan tidak berfikir, atau jika dikaitkan dengan topik ini maka dapat ditafsirkan sebagai ketiadaan rencana jika harga BBM mengalami kenaikan.

\section{Kartun Monolog (Dilema Rokok)}

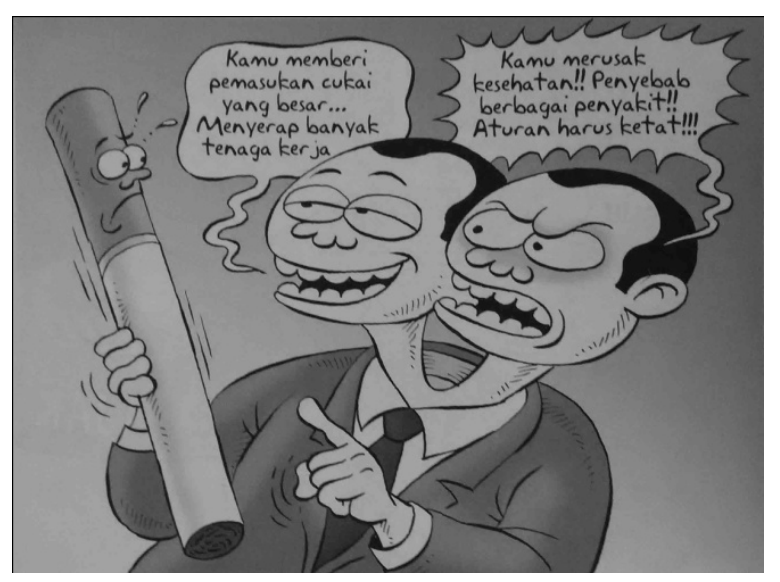

Gambar 3 Kartun Komik "Dilema Rokok" (Sumber: Benny Rachmadi, 2014) 


\section{a. Isi Wimba}

Kartun komik memperlihatkan seorang pria dengan dua kepala sedang memegang rokok. Pria ini digambar dari perut sampai kepala, menghadap ke kiri, berbadan gemuk, rambut pendek rapi, memakai kemeja putih, jas kantor, dan berdasi. Wajah kanan dan kiri kepala mempunyai karakter yang sama tetapi menunjukkan ekspresi yang berbeda. Raut wajah dari kepala di sebelah kiri menunjukkan mata setengah terbuka, alis diangkat, dan mulut terbuka dalam kondisi tersenyum. Sedangkan raut wajah yang dimiliki kepala sebelah kanan memperlihatkan mata melotot, alis beradu, dan garis mulut melengkung ke bawah (mulut dalam kondisi terbuka).

Terdapat dua balon ucapan di atas kepala pria. Balon ucapan di sebelah kiri atas berbentuk panjang meliuk berisi tulisan "Kamu memberi pemasukan cukai yang besar...Menyerap banyak tenaga kerja". Sedangkan balon ucapan di sebelah kanan atas berbentuk panjang bergerigi dan berisi tulisan "Kamu merusak kesehatan!! Penyebab berbagai penyakit!! Aturan harus ketat!!!”.

Gambar rokok yang dipegang pria divisualisasikan dalam ukuran jauh lebih besar, jika cara mengukur berlandaskan pada anatomi pria tersebut. Selain itu pada bagian filter rokok diberi wajah. Mata bulat rokok melihat ke arah pria, alis kanan melengkung ke atas sedangkan alis kiri dan garis mulut melengkung ke bawah.

\section{b. Cara Wimba}

Kartun komik memperlihatkan pemerintah berkepala dua sedang memegang sebatang rokok dengan tangan kanan sementara tangan kirinya menunjuk ke arah rokok tersebut seperti sedang memberi peringatan. Gambar ini menggunakan sudut pandang mata manusia dan digambar medium close up. Wimba rokok dan wimba pria digambar dari sudut tiga perempat tampak depan diatas background polos bergradasi.

Kalimat ucapan pemerintah ditulis menggunakan huruf cursive. Adapun kedudukan teks sejajar dengan kedudukan visual, atau yang disebut Scott McCloud sebagai Interdependent. Semua garis yang digunakan baik yang membentuk bidang, teks maupun garis gerak merupakan jenis garis tebal tipis. Keseragaman penggunaan garis memberikan kesan kesatuan. Menggunakan teknik arsir. Tata letak gambar membentuk keseimbangan asimetris, dimana bidang muatan sisi kanan dan sisi kiri sama besar tetapi berbeda bentuk. Dilihat dari kata dan tata bahasa, tidak satupun yang menunjukkan kronologi waktu. Artinya kartun komik ini dapat dibaca dari kanan ke kiri atau kiri ke kanan.

\section{c. Ungkapan Dalam}

Kartun komik ini diunggah di situs resmi majalah Kontan pada selasa tanggal 24 April 2012 dengan judul "Dilema Rokok". Dari data tersebut dapat diketahui bahwa pada tahun 2012 pemerintah Indonesia berniat mengkaji ulang tata aturan rokok. Sayangnya para pembuat kebijakan selalu saja dihadapkan dengan masalah klasik namun sangat mengusik terkait dampak positif maupun dampak negatif dari rokok yang masih dirasa sama besar.

Problematika tersebut direkam dalam sebuah cerita tentang pemerintah berkepala dua yang sedang memegang rokok. Kepala 
kanan mempunyai raut wajah yang ramah, matanya menatap sayu ke arah rokok, mulutnya tersenyum lebar sambil berkata "Kamu memberi pemasukan cukai yang besar...Menyerap banyak tenaga kerja”. Bentuk meliuk memberikan kesan ramah dan santai, kondisi ini seirama dengan ekspresi wajah dan bagian kepalanya (kanan,identik dengan citra positif).

Kondisi tersebut jauh berbeda dengan raut wajah kepala kiri yang tampak marah sambil berkata "Kamu merusak kesehatan!! Penyebab berbagai penyakit!! Aturan harus ketat!!!”. Pemilihan bagian kiri tubuh sebagai tempat kepala yang marah semakin memberikan kesan tidak ramah, karena kiri mempunyai citra negatif. Kemudian gesture jari-jemari tangan kiri menunjukkan tanda penolakan, peringatan, dan larangan.

Untuk rokok yang dipegang oleh pemerintah, ukuran tubuhnya digambar jauh lebih besar. Cara penggambaran yang demikian (diperbesar) menunjukkan bahwa rokok mempunyai posisi penting dan sebagai citra dari perannya yang cukup signifikan dalam mempengaruhi kehidupan masyarakat Indonesia. Bagian filter rokok ditambahkan wajah dan ekspresi kebingungan yang menunjukkan respon atas apa yang dilakukan oleh pemerintah. Benny membuat benda mati seolah bernyawa untuk menjadikan gambar lebih hidup dan menguatkan citra hiperbolis yang sebelumnya telah dinyatakan melalui penggambaran dua kepala dalam satu tubuh.

Narasi berita dirangkum dalam gaya cerita sebab akibat. Bagian sebab (rokok) terletakkan di sebelah kiri sedangkan akibat (dilematika pemerintah) terletak di sebelah kanan. Poin utamanya terletak di semua wimba, baik ilustrasi, bentuk balon ucapan, maupun teks di dalamnya. Pada intinya, kartun ini bicara langsung ke pokok permasalahan melalui tokoh yang diwakilkan.

\section{Kartun Monolog (Hantu Geng Motor)}

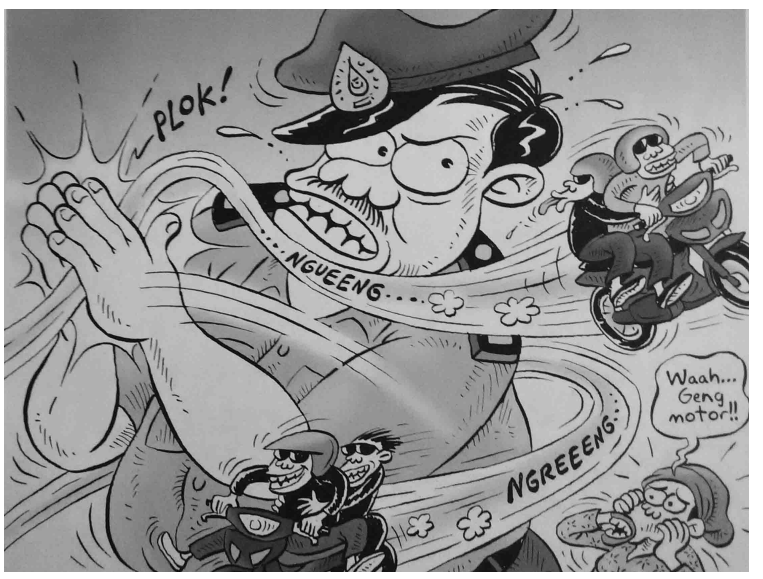

Gambar 4 Kartun Komik "Hantu Genk Motor" (Sumber: Benny Rachmadi, 2014)

a. Panel 1

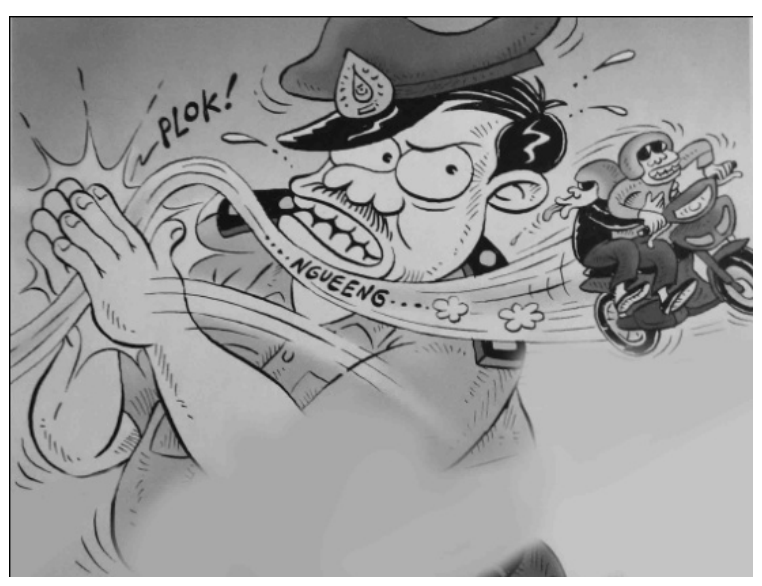

1) Isi Wimba

Terdiri dari tiga pria. Pria pertama sedang menepukkan kedua tangannya, digambar lebih besar dari yang lain, berbadan gemuk, rambut hitam pendek, mata melotot, mulut meringis, berkumis, memakai ikat pinggang, kemeja lengan pendek, dan penutup kepala. Pria ke dua dan ke tiga sedang menaiki motor. Keduanya sama-sama memakai 
kacamata hitam, sepatu hitam, penutup kepala, celana panjang dan baju lengan panjang. Pria ke dua menghadap ke depan dengan mulut meringis sedangkan pria ketiga menoleh ke belakang sambil menjulurkan lidah dan memeluk pria ke dua. Terdapat teks berbunyi “PLOK!” dan “.... NGUEENG ....”

\section{2) Cara Wimba}

Wimba polisi digambar jauh lebih besar dengan wimba geng motor digambar dari sudut tiga perempat tampak depan di atas background polos bergradasi dari atas berwarna gelap kemudian ke bagian bawah semakin terang. Cara pengambilan gambar menggunakan long shot dari sudut pandang mata manusia, menggunakan teknik arsir, garis tebal tipis, dan garis gerak.

Susunan wimba membentuk keseimbangan asimetris dan mengarahkan audience membacanya dari kiri ke kanan, kesimpulan ini berdasarkan pada arah gerak lintasan dari geng motor. Cara penggabungan gambar dan teks termasuk gambar spesifik, dimana unsur visual memuat lebih banyak informasi dibandingkan dengan unsur verbal.

\section{3) Tata Ungkapan Dalam}

Kasus tersebut divisualisasikan dengan pendekatan satir, melibatkan tokoh yang terkait langsung dengan jalannya konflik, yakni polisi dan geng motor. Kinerja polisi dalam menangkap geng motor digambar seperti orang sedang menangkap nyamuk. Polisi digambar besar agar terlihat menonjol dan menyatakan bahwa polisi adalah bagian terpenting.

Geng motor sendiri terlihat mengejek polisi dan bertindak semaunya. Meskipun geng motor terkenal sebagai pemberontak yang nekat dan pemberani, mereka tetap memperhatikan tingkat keselamatan dengan cara memakai helm motor model open face. Motor yang dikendarai adalah motor bebek. Motor jenis ini lebih friendly, cocok digunakan baik pria maupun wanita, populasinya mendominasi jumlah motor di tanah air, dan dari segi harga dapat dikatakan murah sehingga terjangkau oleh banyak kalangan. Gambar ini membantu merekam jenis motor yang pernah mendominasi pasar di Indonesia. Pada intinya panel ini bicara langsung ke pokok masalah. Unsur visual lebih mendominasi dan bercerita lebih banyak.

b. Panel 2

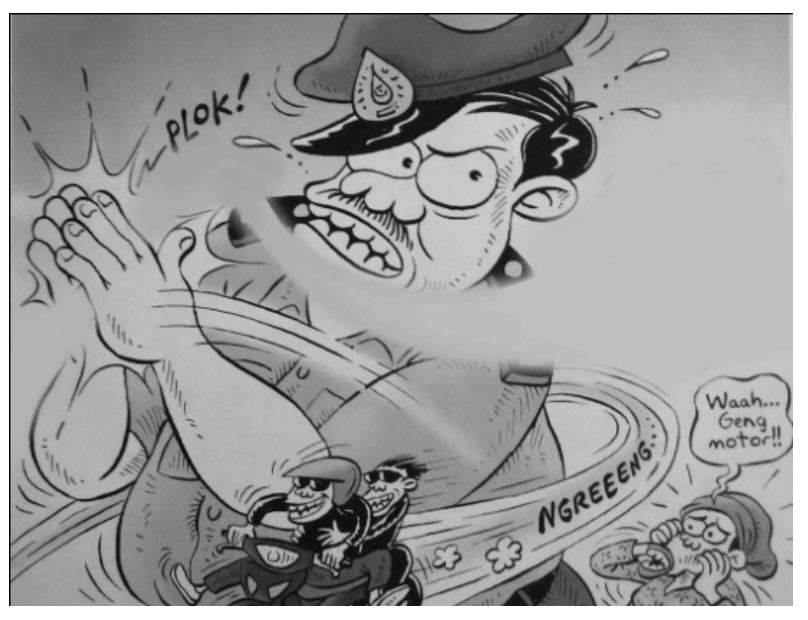

1) Isi Wimba

Terdiri dari tiga pria dan seorang ibu-ibu. Pria pertama berwujud sama dengan pria pada panel pertama. Pria ke dua dan ke tiga sedang menaiki motor, keduanya memakai baju lengan panjang warna hitam, celana panjang, kacamata hitam, sepatu, dan penutup kepala pada pria ke dua. Selain itu terdapat teks berbunyi "PLOK!”, “.... 
NGUEENG ....", “NGREEENG ...., dan kalimat "Waah ... Geng motor!!”.

2) Cara Wimba

Wimba polisi digambar jauh lebih besar dengan wimba geng motor dan wimba ibuibu. Semua wimba tersebut digambar dari sudut tiga perempat tampak depan di atas background polos bergradasi dari atas berwarna gelap kemudian ke bagian bawah semakin terang. Cara pengambilan gambar menggunakan teknik long shot dilihat dari sudut pandang mata manusia, menggunakan teknik arsir, garis tebal tipis, dan garis gerak. Tata letak wimba membentuk keseimbangan asimetris dan mengarahkan audience membacanya dari kiri ke kanan kemudian kanan ke kiri, kesimpulan ini berdasarkan pada arah gerak lintasan geng motor. Cara penggabungan gambar dan teks termasuk duo spesifik, keberadaan keduanya saling melengkapi satu sama lain.

\section{3) Tata Ungkapan Dalam}

Konsep panel kedua serupa dengan panel pertama, melibatkan tokoh yang terkait langsung dengan konflik, yakni polisi dan geng motor. Kinerja polisi dalam menangkap geng motor digambar seperti orang yang sedang menangkap nyamuk. Polisi juga digambar besar karena merupakan bagian terpenting dalam kartun komik. Pada panel ini hadir seorang warga yang takut pada geng motor. Warga tersebut diwakilkan oleh ibuibu dari kelas ekonomi menengah. Karakter nyata dari ibu-ibu dianggap mampu mencerminkan kondisi warga pada masa itu, masa dimana warga dalam posisi lemah, membutuhkan uluran tangan dan perlindungan.
Ibu-ibu ini merupakan salah satu karakter tetap dari Benny Rachmadi yang dapat ditemukan di beberapa kartun komik lainnya. Hadirnya karakter ini menguatkan identitas dan ciri yang membedakan kartun karya Benny dengan kartun karya kartunis lainnya. Panel kedua ini bercerita lebih banyak, bicara langsung ke pokok masalah dan perumpamaan melebur dengan pesan utama. Unsur visual dan unsur verbal saling melengkapi sehingga diperoleh informasi yang utuh.

\section{c. Tata Ungkapan Luar}

Cara penggambaran mirip dengan cara yang digunakan pada relief candi Borobudur, cara yang disebut Primadi Tabrani sebagai ruang waktu datar, dimana ruang dan waktu terekam dalam satu panel. Polisi hanya digambar satu kali dan dibuat besar untuk menyatakan bahwa polisi merupakan bagian terpenting.

Geng motor dari masing-masing panel digambar dengan rupa dan lintasan yang berbeda. Hal ini menujukkan geng motor tersebut berasal dari kawanan yang berbeda, menunjukkan terjadinya peralihan ruang dan waktu. Pada panel pertama tokoh yang terlibat terdiri dari polisi dan geng motor, tetapi pada panel ke dua, warga sipil mulai terlibat di dalamnya. Pergantian pemeran semakin menguatkan adanya pergerakan peralihan ruang maupun waktu dalam satu panel.

Arah baca kartun komik ini zigzag dimulai dari kiri ke kanan, dari kanan ke kiri bawah. Cara baca demikian mirip dengan cara baca lukisan di dinding pemakaman Mesir Kuno. Pada intinya, kartun komik ini banyak mengadopsi tata bahasa rupa Timur. 


\section{Kesimpulan}

Selama proses penelitian terhadap kartun karya Benny Rachmadi dalam buku "PR buat Presiden" melalui pendekatan teori bahasa rupa yang digagas oleh Primadi Tabrani, dapat dipahami bahwa simbol atau perumpaan yang digunakan kartun komik tidak perlu terlalu muluk-muluk. Begitu pula dengan pengemasannya, ketika hanya menggunakan satu bingkai, unsur visual maupun verbal yang dipilih adalah unsur terdekat dari topik permasalahan, dan kadangkala cukup diwakilkan oleh satu objek yang mampu merepresentasikan yang lainnya. Cara bertutur langsung ke pokok pikiran utama dan meletakannya di semua unsur gambar baik objek utama maupun latar sehingga gambar tampak lebih ringkas, padat, dan jelas. Keberagaman jenis kartun ternyata mempengaruhi keberagaman tata bahasa rupa yang digunakan, penempatan peran visual dan verbal. Kartun tanpa balon kata akan lebih mengandalkan visual, sehingga gesture dan ekspresi sangat dibutuhkan. Sedangkan kartun dengan balon kata akan lebih mengandalkan verbal dan visual secara seimbang.

Penelitian ini membawa pemahaman baru terkait salah satu teori yang dapat dijadikan sebagai alternatif dalam mengkaji dan memahami sebuah konsep desain berupa kartun komik. Tahap demi tahap yang harus dilalui pada dasarnya tidak jauh berbeda dengan teori-teori lain, tetapi pengalaman dan pelajaran yang diperoleh jauh berbeda.

\section{DAFTAR PUSTAKA}

\section{Buku}

[1] Ajidarma, Seno Gumira. 2012. Antara Tawa dan Bahaya Kartun dalam Politik Humor.Jakarta: Kepustakaan Populer Gramedia.

[2] Dharmamulya, Sukirman dkk.2008.Permainan Tradisional Jawa: Sebuah Upaya Pelestarian. Yogyakarta: Kepel Press.

[3] Maharsi, Indiria.2011.Komik: Dunia Tanpa Batas.Yogyakarta: Kata Buku.

[4] Margana, Sri dkk.2014.Kretek Indonesia: Dari Nasionalisme Hingga Warisan Budaya.Yogyakarta: Puskindo.

[5] McCloud, Scott.2008.Understanding Comics Memahami Komik.Jakarta: Kepustakaan Populer Gramedia.

[6] Rachmadi, Benny.2014. PR buat Presiden.Jakarta: Kepustakaan Populer Gramedia.

[7] Rustan, Surianto.2010.Font dan Tipografi. Jakarta: Penerbit PT Gramedia Pustaka Utama.

[8] Santana, Septiawan.2010.Menulis Ilmiah Metode Penelitian Kualitatif.Jakarta: Yayasan Obor.

[9] Tabrani, Primadi.2012.Bahasa Rupa. Bandung: Penerbit Kelir.

[10] Wibisono, Nuran dan Marlutfi Yoandinas.2014. Kretek: Kemandirian dan Kedaulatan Bangsa Indonesia.Jakarta: Koalisi Nasional Penyelamatan Kretek.

[11] Wijana, I Dewa Putu.2004.Kartun: Studi Tentang Permainan Bahasa. Yogyakarta: Penerbit Ombak.

[12] Zakaria, Imam.2014.Kajian Ikonografi Disain Grafis Sampul Buletin "Brosur Lebaran"mKotagede Tahun 1976-2010. Tugas Akhir S-1 Disain Komunikasi Visual, Fakultas Seni Rupa Institut Seni Indonesia Yogyakarta. 